Original Article

\title{
Hematological and renoprotective effects of folic acid and lentil extract in diclofenac sodium exposed rats
}

\author{
Efeitos hematológicos e renoprotetores do ácido fólico e do extrato de lentilha em \\ ratos expostos ao diclofenaco de sódio
}

Omnia N. Abdel-Rahmanª and Enas S. Abdel-Baky** (1)

a Department of Biological and Geological Sciences, Faculty of Education, Ain Shams University, Cairo, Egypt

\begin{abstract}
Excessive intake of non-steroidal anti-inflammatory drugs such as, diclofenac sodium (DS) may lead to toxicity in the rats. In this work, we aimed to examine the protective impact of lentil extract (LE) and folic acid (FA) on the hematological markers, the kidney tissue oxidative stress and the renal function against diclofenac sodium (DS) in male albino rats. The rats (120-150 g) were divided into four equal groups randomly, the first group kept as the untreated control. The second group was administrated with DS (11.6 mg/kg b.wt. orally once/day). The third group was received DS+FA (11.6 mg/kg b.wt.+76.9 microgram $/ \mathrm{kg}$ b.wt.) orally once/day. The fourth group was treated with DS+LE (11.6 mg/kg b.wt. $+500 \mathrm{mg} / \mathrm{kg}$ b.wt.) orally once/day. After four weeks, the results revealed that DS produced a significant decrease in the values of red blood cells (RBCs), hemoglobin concentration (Hb), hematocrit (HCT) and white blood cells (WBCs). On the other hand, there was a significant increase in the platelets count. Also, DS induced a renal deterioration; this was evidenced by the significant increase in the serum levels of urea, creatinine, uric acid, $\mathrm{Na}, \mathrm{Ca}, \mathrm{Mg}$ as well as the nitric oxide (NO) level in the kidney tissue. Also, there were a significant reduction in the serum levels of potassium (K) and reduced glutathione (GSH) in the kidney homogenates. Moreover, the findings in the rats treated by DS+LE or DS+FA showed a potential protection on the hematological markers, oxidative stress in the kidney tissue and the renal function disturbed by DS.

LE and FA could play a potent role for the prevention the adverse hematological, the kidney tissue oxidative stress and the renal dysfunction caused by DS via their anti-oxidative and bioactive phytochemicals.
\end{abstract}

Keywords: lentil extract, folic acid, diclofenac sodium, hematological markers, renal function, oxidative stress.

\begin{abstract}
Resumo
A ingestão excessiva de anti-inflamatórios não esteroidais, como o diclofenaco de sódio(DS), pode causar toxicidade em ratos. Neste trabalho, objetivamos examinar o impacto protetor do extrato de lentilha (LE) e ácido fólico (AF) em marcadores hematológicos, no estresse oxidativo do tecido renal e na função renal contra o diclofenaco de sódio (DS) em ratos albinos machos. Os ratos (120-150 g) foram divididos em quatro grupos iguais aleatoriamente, sendo o primeiro grupo mantido como controle não tratado. O segundo grupo foi administrado com DS (11,6 mg / kg de peso corporal por via oral uma vez / dia). O terceiro grupo recebeu DS + FA (76,9 mg / kg de peso corporal por via oral uma vez / dia). O quarto grupo foi tratado com DS + LE (500 mg / kg de peso corporal por via oral uma vez / dia). Após quatro semanas, os resultados revelaram que o DS produziu uma diminuição significativa nos valores de glóbulos vermelhos (RBCs), concentração de hemoglobina (Hb), hematócrito (HCT) e glóbulos brancos (WBCs). Por outro lado, houve um aumento significativo na contagem de plaquetas. Além disso, o DS induziu uma deterioração renal; isso foi evidenciado pelo aumento significativo dos níveis séricos de ureia, creatinina, ácido úrico, $\mathrm{Na}$, $\mathrm{Ca}$, Mg e também do nível de óxido nítrico no tecido renal. Além disso, houve uma redução significativa nos níveis séricos de potássio $(\mathrm{K})$ e glutationa reduzida $(\mathrm{GSH})$ nos homogenatos renais. Além disso, os achados nos ratos tratados com DS + LE ou DS + FA mostraram uma proteção potencial sobre os marcadores hematológicos, estresse oxidativo no tecido renal e função renal perturbada pelo DS. LE e AF podem desempenhar um papel potente na prevenção do estresse hematológico adverso, do estresse oxidativo do tecido renal e da disfunção renal causada pelo DS por meio de seus fitoquímicos antioxidantes e bioativos.
\end{abstract}

Palavras-chave: extrato de lentilha, ácido fólico, diclofenaco sódico, hematológico, função renal, estresse oxidativo. 


\section{Introduction}

Non-steroidal anti-inflammatory drugs (NSAIDs) are usually used in the case of acute muscle pain conditions, for their analgesic properties and their anti-inflammatory activities (Crofford, 2013). The use of normal doses from NSAIDs causes gastrointestinal incompatibility. However, the high doses consumption of these drugs may lead to toxicity (Laneuville et al., 1994), ranging from acute to long-term chronic disorders, including renal diseases and cardiovascular disorders (Essex et al., 2013), and affect oxidative balance in the body (Yapar et al., 2008). Diclofenac sodium (DS) is one of these NSAIDs used to decrease arthritis-associated pain and inflammation (Blair and Plosker, 2015; Hoy, 2016). It is absorbed efficiently from the gastrointestinal tract and has a short elimination half-life of 2-3 hours in most species, with an average of 1.5 hours in plasma and accumulates at the site of inflammation and persists in synovial fluid (El-Maddawy and El-Ashmawy, 2013). Diclofenac could induce hepatorenal toxicity (Alabi and Akomolafe, 2020), and it may cause many changes in some organs of the body, such as kidney, heart, and stomach (Abdel-Daim et al., 2018).

$B$ vitamins group are a water-soluble including folic acid (FA), thiamine, biotin, riboflavin, pyridoxine, cobalamin, inositol, choline, and para-aminobenzoic acid (PonceMonter et al., 2012). Folate is required for purine and pyrimidine nucleotides synthesis (precursors of DNA and RNA, respectively), and for the metabolism of several amino acids including homocysteine (Lucock, 2000). The deficiency of folate may lead to folate-dependent metabolic pathways disruption, causing the development of clinical abnormalities starting from anemia to growth retardation (Krishnan and Kiernan, 2009). Some of these vitamins used alone or in combination with diclofenac or other NSAIDs for many painful diseases like polyneuropathies and the spinal column degenerative diseases, and the inflammation treatment resulting from the deficiency of the vitamin (Mibielli et al., 2009).

Previous research reported that FA administrations can alleviate the risk of cardiovascular and hematological diseases (Verhaar et al., 2002). Also, FA has the ability to ameliorate oxidative induced kidney damage by lowering levels of lipid peroxidation and stimulating the antioxidant defense system (Ebaid et al., 2020). In fact, FA has been reported to alleviate the hyperhomocysteinemia and its associated endothelial dysfunction (Moens et al., 2008). Moreover, the anti-inflammatory effect of FA is proved by the decreasing levels of C-reactive proteins and interleukin (Solini et al., 2006).

Usage of the plants in medicine for both curative and preventive is an age-long practice in the world. About $80 \%$ of the population depends on preparations of these plants as medicine for their health demands (Ogbera et al., 2010). Today, pulses are important in the field of functional foods and developing healthy. Numerous articles reviewed the nutritional components and the phytochemicals bioactive of pulses and their uses for the health (Dilis and Trichopoulou, 2009). Lentils had gained much interest due to their unique nutritional and functional characteristics (Faris et al., 2013). The lentil extract (LE), Lens culinaris (family: Leguminoceae), is considered as one of the most important traditional dietary components (FAO, 1998). It was reported that lentils world production was about 2.83 million metric tons for 2008 (FAOSTAT, 2011). It is a significant dietary source of vitamins including folate, thiamin (B1) and riboflavin (B2) (USDA, 2011). LE had a higher Oxygen Radical Absorbing Capacity (ORAC) value more than the common fruits and vegetables including apples, pears, blackberries, figs, cherries, cabbage, oranges, garlic, and almonds (USDA, 2010). Lentil seeds are used today in the folk medicine to treat different illnesses. They are used to treat diabetes, the treatment of burns and topically as a water paste to treat skin infections (Faris et al., 2013).

This work was designed to estimate the toxic effect of DS and the protective effect of the treatment with FA and LE in the rats treated with DS on some hematological parameters, oxidative stress tissue markers of the kidney (NO and GSH), the serum markers of kidney damage (urea, uric acid and creatinine concentrations) and the electrolytes levels (Sodium, Calcium, Potassium, and magnesium).

\section{Methods}

\subsection{Medicinal plants and chemical compounds}

\subsubsection{Drugs used in the experiment were:}

Diclofenac sodium (DS) tablets (diclac, $150 \mathrm{mg} / \mathrm{kg}$ ), manufactured by Minapharm, Hexal AG, Egypt. The dose of DS (11.6 mg/kg b.wt. orally once/day) were calculated by the equivalent therapeutic dosages of human-mouse conversion factor (Paget and Barnes, 1964), and were given for four weeks.

Folic acid (FA) tablets (1000 mcg/kg) were obtained from Sigma Chemical Company, Louis, MO, USA., the dose of folic acid (76.9 microgram/kg b.wt. orally once/day) were calculated by the equivalent therapeutic dosages of human-mouse conversion factor (Paget and Barnes, 1964), and were given for four weeks.

Lentil Extract (LE) Preparation: the dry seeds of red lentil were obtained from a farm, Egypt. $500 \mathrm{~g}$ red lentil seeds were crushed into small pieces and soaked in a $70 \%$ aqueous-ethanol solution in a large container for 3 days with regular shaking. Then, it was filtered by a clean cotton cloth and dried using a rotary evaporator at $40^{\circ} \mathrm{C}$ for 8 hours to produce a 20 -gm powder and was diluted with distilled water to obtain the appropriate used oral dose of LE (500 mg/kg b.wt.) (Houshmand et al., 2016).

\subsection{Animals and experimental design}

Adult male rats (120-150 g) were obtained from Schistosoma Biological Supply Program (SBSP), Theodor Bilharz Research Institute, Cairo, Egypt. They were kept under normal conditions during the whole period of the experiment. All rats were fed on standard food, and they were allowed free access to water and food, with 12hour day and night cycle. They were kept for 10 days for the adaptation before the beginning of the experiment. 
An animal experiment was conducted according to the guidelines of the institutional animal ethics committee in accordance with the university.

After animals being acclimatized with the experimental conditions, they were divided into four groups randomly (6 animals each). Group (1) normal rats kept as the untreated rats and act as control. Group (2) animals administrated orally with DS ( $11.6 \mathrm{mg} / \mathrm{kg}$ b.wt. once/day). Group (3) animals administrated orally with DS (11.6 mg/ kg b.wt. once/day) + FA (76.9 microgram/kg b.wt. once/ day). Group (4) animals administrated orally with DS (11.6 $\mathrm{mg} / \mathrm{kg}$ b.wt. once/day) + LE (500 mg/kg b.wt. once/day).

\subsection{Blood and tissue sampling}

After four weeks of administration, animals have fasted overnight, the rats were anesthetized with chloroform and the blood were collected into vacutainer collecting tubes from the retro-orbital plexus and left 20 minutes to clot, then centrifuged at $3000 \mathrm{rpm}$ for 10 minutes using cooling centrifuge. The sera were separated, and stored at $-20^{\circ} \mathrm{C}$. After blood collection, the animals were dissected and the kidney of each animal was dissected out, washed with saline, dried, rolled in aluminum foil piece, and stored at $-80^{\circ} \mathrm{C}$ for antioxidant determinations.

\subsubsection{Determination of hematological parameters}

Blood samples were collected on heparinized capillary tubes for haermatocrit value (HCT). It is measured after entering the blood into a capillary tube plugged by plastic seal and centrifuged for $5 \mathrm{~min}$ at 1200 r.p.m. (Rodak, 1995). Red and white blood cells were counted by improved haemocytometer (Dacie and Lewis, 1991). Hemoglobin concentration was estimated in $\mathrm{gm} / \mathrm{dl}$ blood (Dacie and Lewis, 1991). Platelets count also was performed by the method of Dacie and Lewis (1991).

\subsubsection{Biochemical analysis}

Urea and uric acid were estimated according to Young (2001). Creatinine was measured according to Bartels and Bobmer (1972) method. Sodium and potassium were determined according to Tietz (1987), calcium was estimated according to Faulker and Meites (1982) method. Determination of magnesium in blood sera was recorded according to Szívós and Pungor (1974).

\subsubsection{Determination of Nitric Oxide (NO) and Reduced Glutathione (GSH) in the kidney tissue homogenates}

Nitric oxide was determined calorimetrically according to the method described by Montgomery and Dymock (1961), and reduced glutathione was measured by the method of Beutler et al. (1963).

\subsection{Statistical analysis}

The obtained data were statistically analyzed using SPSS program (Version 16) Glantz (1992). Significant differences among groups were determined by one-way analysis of variance (ANOVA). This was followed by post hoc test using Duncan test to compare significance between groups at $\mathrm{p}$-value $<0.05$.

\section{Results}

Table 1 showed that the administration of diclofenac sodium (DS) orally at $11.6 \mathrm{mg} / \mathrm{kg}$ b.wt. once/day leads to a significant reducing in RBCs, Hb, HCT and WBCs values compared to the control rats. Whereas the platelets count showed a significant increase comparing with the control ones. On the other hand, the treatment with DS plus folic acid (FA) and the DS plus lentil extract (LE) showed normal values in these hematological markers. Co-administration of DS+FA or DS+LE was significantly prevented to some extent the changes recorded in the DS group in these parameters as compared with the control group.

In comparison to the control group, the animals treated with DS showed a significant increase in the serum urea, uric acid, and creatinine levels. Whereas the animals those were treated with DS combined with FA and DS combined with LE showed a significant decrease in the urea, uric acid and creatinine levels in compared to animals that received DS only (Table 2 ).

Table 3 shows the effect of DS on sodium, calcium, potassium, and magnesium levels; the obtained data declared that administration of DS induced a significant elevation in the serum sodium, calcium and magnesium levels coupled with the reduction in the serum potassium level, when all were compared to the control group. With respect to group of the animals treated with combination between DS plus FA or DS plus LE, the animals revealed a significant alleviating in the serum sodium level with a marked increase in the potassium level comparing with DS

Table 1. Effect of orally administrated DS, DS+FA and DS+LE on the hematological parameters in male albino rats.

\begin{tabular}{lcccccccc}
\hline \multicolumn{1}{c}{ Parameters } & Group I (C) & $\begin{array}{c}\text { Group II } \\
\text { (DS) }\end{array}$ & D \% & $\begin{array}{c}\text { Group III } \\
(\text { DS+FA) }\end{array}$ & D\% & $\begin{array}{c}\text { Group IV } \\
(\text { DS+LE) }\end{array}$ & D\% & p-value \\
\hline RBCs $(\times 106 / m m 3)$ & $6.84^{\mathrm{a}} \pm 0.10$ & $3.41^{\mathrm{b}} \pm 0.2$ & $-50.15 \%$ & $5.8^{\mathrm{c}} \pm 0.3$ & $-15.20 \%$ & $5.7^{\mathrm{c}} \pm 0.3$ & $-16.6 \%$ & $*$ \\
$\mathbf{H b}(\mathrm{g} / \mathrm{dl})$ & $13.5^{\mathrm{a}} \pm 0.23$ & $6.7^{\mathrm{b}} \pm 0.31$ & $-50.37 \%$ & $12.82^{\mathrm{a}} \pm 0.4$ & $-5.04 \%$ & $11.7^{\mathrm{c}} \pm 0.3$ & $-13.33 \%$ & $*$ \\
$\mathbf{H C T}(\%)$ & $35.33^{\mathrm{a}} \pm 0.3$ & $20.4^{\mathrm{b}} \pm 0.34$ & $-42.26 \%$ & $35.3^{\mathrm{a}} \pm 0.8$ & $-.08 \%$ & $29.2^{\mathrm{c} \pm 0.6}$ & $-17.35 \%$ & $*$ \\
$\mathbf{P L T}\left(\times 103 / \mathrm{mm}^{3}\right)$ & $398.33^{\mathrm{a}} \pm 0.9$ & $515.33^{\mathrm{b}} \pm 2$ & 29.4 & $804.33^{\mathrm{c}} \pm 3.8$ & 101.9 & $490.8^{\mathrm{d}} \pm 2.8$ & 23.21 & $*$ \\
$\mathbf{W B C s}(\times 109 / \mathrm{L})$ & $13.7^{\mathrm{a}} \pm 0.22$ & $3.9^{\mathrm{b}} \pm 0.15$ & $-71.53 \%$ & $13.2^{\mathrm{a}} \pm 0.4$ & $-3.65 \%$ & $13.3^{\mathrm{a}} \pm 0.4$ & $-2.92 \%$ & $*$ \\
\hline
\end{tabular}

*Values represent mean \pm S.E. \% D: Percentage difference [ (Treated value - Control Value) / Control Value] x 100 Different letters indicate significantly different means p-value $<0.05$; Same letters indicate non-significant changes. 
Table 2. Effect of orally administrated DS, DS+FA and DS+LE on the urea, uric acid and creatinine levels in male albino rats.

\begin{tabular}{lcccccccc}
\hline \multicolumn{1}{c}{ Parameters } & Group I (C) & Group II (DS) & D \% & $\begin{array}{c}\text { Group III } \\
\text { (DS+FA) }\end{array}$ & D\% & $\begin{array}{c}\text { Group IV } \\
\text { (DS+LE) }\end{array}$ & D\% & p-value \\
\hline Urea $(\mathrm{mg} / \mathrm{dl})$ & $23.4^{\mathrm{a}} \pm 0.3$ & $44.6^{\mathrm{b}} \pm 0.43$ & $90.59 \%$ & $31.2^{\mathrm{c}} \pm 1$ & $33.33 \%$ & $24.5^{\mathrm{a}} \pm 0.8$ & $4.7 \%$ & $*$ \\
Uric acid $(\mathrm{mg} / \mathrm{dl})$ & $1.1^{\mathrm{ac}} \pm 0.1$ & $1.7^{\mathrm{b}} \pm 0.1$ & $54.54 \%$ & $1.3^{\mathrm{ac}} \pm 0.1$ & $18.18 \%$ & $1.3^{\mathrm{ac}} \pm 0.1$ & $18.18 \%$ & $*$ \\
Creatinine $(\mathrm{mg} / \mathrm{dl})$ & $0.44^{\mathrm{a}} \pm 0.02$ & $0.67^{\mathrm{b}} \pm 0.02$ & $52.27 \%$ & $0.51^{\mathrm{c}} \pm 0.02$ & $15.9 \%$ & $0.5^{\mathrm{c}} \pm 0.02$ & $13.63 \%$ & $*$ \\
\hline
\end{tabular}

*Values represent mean \pm S.E. \% D: Percentage difference [ (Treated value - Control Value)/Control Value] x 100 Different letters indicate significantly different means p-value $<0.05$; Same letters indicate non-significant changes.

Table 3. Effect of orally administrated DS, DS+FA and DS+ LE on the calcium, sodium, potassium and magnesium levels in male albino rats.

\begin{tabular}{lcccccccc}
\hline \multicolumn{1}{c}{ Parameters } & $\begin{array}{c}\text { Group I } \\
\text { (C) }\end{array}$ & $\begin{array}{c}\text { Group II } \\
\text { (DS) }\end{array}$ & D \% & $\begin{array}{c}\text { Group III } \\
\text { (DS+FA) }\end{array}$ & D\% & $\begin{array}{c}\text { Group IV } \\
\text { (DS+LE) }\end{array}$ & D\% & p-value \\
\hline Sodium $(\mathrm{mmol} / \mathrm{l})$ & $1.36^{\mathrm{a}} \pm 0.5$ & $1.66^{\mathrm{b}} \pm 1$ & $22.06 \%$ & $1.43^{\mathrm{c}} \pm 1$ & $5.15 \%$ & $1.36^{\mathrm{a}} \pm 0.8$ & $0 \%$ & $*$ \\
Potassium $(\mathrm{mmol} / \mathrm{l})$ & $5.9^{\mathrm{a}} \pm 0.1$ & $4.37^{\mathrm{b}} \pm 0.23$ & $-5.93 \%$ & $6.7^{\mathrm{c}} \pm 0.14$ & $13.56 \%$ & $7.2^{\mathrm{d}} \pm 0.23$ & $22.03 \%$ & $*$ \\
Calcium $(\mathrm{mg} / 100 \mathrm{ml}$ & $9.23^{\mathrm{a}} \pm 0.1$ & $9.98^{\mathrm{b}} \pm 0.1$ & $8.12 \%$ & $10.13^{\mathrm{b}} \pm 0.2$ & $9.75 \%$ & $10.4^{\mathrm{b} c \pm 0.14}$ & $12.68 \%$ & $*$ \\
Magnesium $(\mathrm{mmol} / \mathrm{l})$ & $1.48^{\mathrm{a}} \pm 0.48$ & $2.02^{\mathrm{b}} \pm 0.1$ & $36.49 \%$ & $1.72^{\mathrm{c}} \pm 0.1$ & $16.22 \%$ & $1.83^{\mathrm{bc} \pm 0.1}$ & $23.65 \%$ & $*$ \\
\hline
\end{tabular}

*Values represent mean \pm S.E. \% D: Percentage difference [ (Treated value - Control Value)/Control Value] x 100 Different letters indicate significantly different means p-value < 0.05 ; Same letters indicate non-significant changes.

Table 4. Effect of orally administrated DS, DS+FA and DS+ LE on the NO and GSH levels in male albino rats.

\begin{tabular}{lcccccccc}
\hline \multicolumn{1}{c}{ Parameters } & $\begin{array}{c}\text { Group I } \\
\text { (C) }\end{array}$ & $\begin{array}{c}\text { Group II } \\
\text { (DS) }\end{array}$ & D \% & $\begin{array}{c}\text { Group III } \\
\text { (DS+FA) }\end{array}$ & D\% & $\begin{array}{c}\text { Group IV } \\
\text { (DS+LE) }\end{array}$ & D\% & p-value \\
\hline NO $(\mu \mathrm{mol} / \mathrm{g})$ & $0.24^{\mathrm{a}} \pm 0.01$ & $0.34^{\mathrm{b}} \pm 0.02$ & $41.67 \%$ & $0.2^{\mathrm{a}} \pm 0.01$ & $-16.67 \%$ & $0.2^{\mathrm{a}} \pm 0.02$ & $-16.67 \%$ & $*$ \\
$\mathbf{G S H}(\mathrm{mmol} / \mathrm{g})$ & $0.3^{\mathrm{a}} \pm 0.02$ & $0.1^{\mathrm{b}} \pm 0.01$ & $-200 \%$ & $0.3^{\mathrm{a}} \pm 0.02$ & $0 \%$ & $0.3^{\mathrm{a}} \pm 0.01$ & $0 \%$ & $*$ \\
\hline
\end{tabular}

*Values represent mean \pm S.E.\% D: Percentage difference [ (Treated value - Control Value)/Control Value] x 100 Different letters indicate significantly different means p-value $<0.05$; Same letters indicate non-significant changes.

group. Calcium level showed an elevation when compared with control and DS treated groups. Finally, magnesium level revealed a slight decrease when compared with DS group.

Comparing with the control group, administration of DS adverse the kidney oxidative stress parameters including, the nitric oxide (NO) and reduced glutathione (GSH) levels. The results showed a significantly raised of NO and depleted GSH levels. On the other side and comparing with DS treated group, the animals treated with DS plus FA or DS plus LE showed a marked improvement in the kidney oxidative stress battery by restoring NO and GSH levels to the control values (Table 4).

\section{Discussion}

Administration of the high dose of non-steroidal antiinflammatory drugs (NSAIDs) such as diclofenac sodium produces several adverse reactions. The purpose of this research was to determine the protective effects of the administration of folic acid (FA) (vitamin B9) and lentil extract (LE) orally against the disturbance induced by the diclofenac sodium (DS) on hematological markers, oxidative stress in the kidney tissue, kidney function and the levels of some electrolytes in male rats.

Hematological estimation gives important information on the body's response to all forms of injury, such as toxic injury (Ihedioha et al., 2004). The current results showed that the oral administration of DS at $11.6 \mathrm{mg} / \mathrm{kg}$ b.wt. stimulated a significant reduction in the RBCs, Hb, HCT and WBCs but the platelets count revealed a significant increase compared to the control rats. These results suggested that the hematotoxic effects of DS administration to the rats characterized by excessive destruction of red blood cells resulting in anemia (Enendu et al., 2016). It may also be due to loss of erythrocytes as a result of gastrointestinal bleeding. When there is a substantial loss of blood from the body, the RBCs picture may indicate microcytic hypochromic anemia. Similar findings were observed by El-Maddawy and El-Ashmawy (2013), who reported that the administration of DS to male rats $(13.5 \mathrm{mg} / \mathrm{kg}$ by $\mathrm{i} / \mathrm{m}$ route for 14 days) induced a significant decrease in RBCs, PCV, Hb and WBCs values compared to the control. The significant decrease in WBCs count observed may be attributed to the decrease in feeds consumption, due to the debilitating effects of DS (Orinya et al., 2016). The elevation in the count of platelets may be due to increased megakaryocytes number in the bone marrow. Since, the platelets count is increased in iron deficiency anemia and correlated inversely with level of hemoglobin (Soltan, 2013).

The supplementation with FA or LE with DS revealed an improvement in the hematological markers. As, FA which is necessary for the synthesis of DNA, therefore it needed by all dividing body cells, particularly haematopoietic cells 
in the bone marrow (Samson et al., 2012), and the cooked lentils containing $9.6 \mathrm{mg} / 100 \mathrm{~g}$ iron (Teclu et al., 2009). Also, the lentils showed higher folate concentration (479 $\mu \mathrm{g} / 100 \mathrm{~g}$ ) (Singh, 2018).

Imbalance between the generation of reactive oxygen species (ROS) or reactive nitrogen species (RNS) and the antioxidant defense system causes oxidative stress (Juránek and Bezek, 2005). ROS and oxidative stress can accelerate the pathogenesis and acute renal dysfunction (Mahmoud et al., 2015). ROS are produced in the body and are deactivated by enzymatic (superoxide dismutase, catalase, glutathione peroxidase, etc.) or non-enzymatic (vitamin A, vitamin C, glutathione, etc.) substances (Macdonald et al., 2003).

Normally, oxidants and antioxidants are in balance in the body. The NSAIDs can alter oxidative balance in the body (Konyalioglu et al., 2007). The mechanism of diclofenac-induced mitochondrial injury may be involved in the generation of ROS, causing renal tissue oxidative stress (Hickey et al., 2001).

In the present work, DS administration significantly reduced renal GSH level and increased the NO level. These findings were in accordance with (Martin and Sabina, 2016). The role of GSH, as non-enzymatic antioxidant, is very important to fight the free radicals resulted from toxic chemicals (Chen et al., 2012). Thus, the ability of renal tissue to overcome the oxidative stress damage caused by DS is reduced.

Whereas the present findings mainly showing the improvement effect of FA and LE on DS induced renal stress in the rats. As, there were a significant increase of GSH level and a significant decrease in NO level comparing with DS treated group. These results confirm the biochemical data in the previous studies which suggested that FA and LE have strong oxygen radical absorbing capacity. Oxidative stress markers were ameliorated by FA supplementation may be due to its direct effect on free-radical oxidation of LDL lipids (Lee et al., 2011). Also, FA has an antioxidant effect, it is reported that its administration decreases the production of ROS (Mutavdzin et al., 2019). The significant result of LE was due to its ability in restoring renal function by restoring antioxidants and preventing cellular damages. Since, the lentil herb has most of the essential nutrients to a person's diet, it contains high levels of vitamins (folates), protein (20\%-30\%) and prebiotic carbohydrates (Thavarajah et al., 2015).

Kidney is the main organ necessary for maintaining body homeostasis, it is a major target for many toxins. Some drugs distort renal perfusion and reduce its filtration capacity, while others directly damage vascular, glomerular, tubular, and interstitial cells (Choudhury and Ahmed, 2006). The results of the present work revealed that, the co-administration of FA or LE with DS induced a decrease in the elevated serum levels of urea, uric acid, creatinine, sodium, calcium, and magnesium in rats as compared with the DS treated rats. On the other hand, it induced an increase in potassium serum level comparing with SD group. The serum levels of blood urea, uric acid and creatinine are indicator markers reflecting the adequate functions of the kidney (Gowda et al., 2010).
The increase in the serum urea, uric acid and creatinine levels in the present study by DS treatment are in line with the previous findings (Adaramoye et al., 2016). Urea is the principal waste product of protein catabolism. Diclofenac sodium probably causes a decrease in glomerular filtration rate (GFR), resulting in decreased excretion of urea, which may produce an increase in the concentration of the blood urea (Ahmad et al., 2012). Diclofenac inhibits both cyclooxygenases and prostaglandins production, which play an important role in maintaining GFR of the kidneys (Dhanvijay et al., 2013). Uric acid is the metabolic product of purine metabolism, when the uric acid metabolic pathway is disrupted, either by over-production of uric acid due to increased purine intake or decreased excretion of uric acid from the kidney due to impaired renal function, hyperuricemia develops and the risk of having gout increases substantially (Lai et al., 2008). Also, previous studies have proved that an increase in serum creatinine can represent a marked decrease in the glomerular filtration rate (Salomon et al., 2003). Thus, diclofenac sodium may alter renal functions through its effect on renal prostaglandins, leading to reduced GFR and accumulation of urea, uric acid and creatinine in the blood.

Serum electrolytes estimations are among the tests of kidney function. The significant elevations in the serum electrolytes including, sodium, calcium, magnesium levels seen in this study may be due to the toxic effect of DS on the kidneys, resulting in reduced GFR and excretion of the ions (Dhanvijay et al., 2013). The kidneys secrete potassium $(\mathrm{K}+)$ ions, reabsorbs $85 \%$ of sodium $(\mathrm{Na}+)$ and also functions in the excretion of these electrolytes (ions), in order to keep acid-base balance under normal physiological conditions (Vasudevan and Sreekumari, 2007). Failure in the regulatory functions of the kidney leads to abnormally high or low levels of these ions in the blood, due to reduced GFR and rate of secretion of these ions. The inhibition of renal prostaglandins synthesis by NSAIDs causes various disturbances in the electrolytes and acid-base including sodium retention, and decreased renal function (Kim and Joo, 2007). Whereas the FA and LE significantly improved these changes induced by DS in the renal failure and electrolytes levels (Sakr et al., 2018).

The improvement in the renal function and serum electrolytes levels were observed in the present study could be attributed to the ability of FA and LE to improve GFR. In addition, the antioxidant activity of both FA and LE as mentioned before may be additional factor role in improving the renal functions. Lentils have prospective health benefits as complementary and alternative medicines, which are present in the form of anti-inflammatory, nephroprotective, antioxidant and chemopreventive activities (Ganesan and Xu, 2017). Also, the mineral content of lentils is composed of relatively high levels of magnesium, potassium, calcium, and sodium. Lentils have a low content of sodium and a relatively high potassium contents, that makes the lentils quite attractive as an important healthy diet for hypertensive patients (Demirbas, 2005). 


\section{Conclusions}

In conclusion, the hematological and renal problems, including renal dysfunctions, oxidative stress and electrolytes imbalance induced by the treatment with diclofenac sodium might be improved by the folic acid and lentil extract administration.

\section{Acknowledgements}

We are grateful to the Department of Biological and Geological Sciences, Faculty of Education, Ain Shams University, for the availability of the place during caring of the animals.

\section{Abbreviations}

ANOVA: one-way analysis of variance; DS: diclofenac sodium; GFR: glomerular filtration rate; GSH: reduced glutathione; Hb: hemoglobin concentration; HCT: hematocrit; K: potassium; LE: lentil extract; NSAIDs: Non-steroidal anti-inflammatory drugs; RBCs: red blood cells; WBCs: white blood cells.

\section{References}

ABDEL-DAIM, M.M., ELTAYSH, R., HASSAN, A. and MOUSA, S.A. 2018. Lycopene attenuates tulathromycin and diclofenac sodium-induced cardiotoxicity in mice. International Journal of Molecular Sciences, vol. 19, no. 2, pp. 344. http://dx.doi. org/10.3390/ijms19020344. PMid:29364179.

ADARAMOYE, O.A., KEHINDE, A.O., ADEFISAN, A., ADEYEMI, O., OYINLOLA, I. and AKANNI, O.O., 2016. Ameliorative effects of Kolaviron, a biflavonoid fraction from Garcinia Kola seed, on hepatorenal toxicity of anti-tuberculosis drugs in wistar rats. The Tokai Journal of Experimental and Clinical Medicine, vol. 41, no. 1, pp. 14-21. PMid:27050890.

AHMAD, I., QURESHI, T.A., KHAN, F.A., MUGHAL, S.A.K., SADIQUE, U., SHAH, Z., KHAN, S. and HASSAN, Z.U., 2012. Evaluation of Biochemical effects of dioclofenac sodium in goats. Journal of Animal and Plant Sciences, vol. 22, no. 2, pp. 1-4.

ALABI, Q.K. and AKOMOLAFE, R.F., 2020. Kolaviron diminishes diclofenac-induced liver and kidney toxicity in wistar rats via suppressing inflammatory events, upregulating antioxidant defenses, and improving hematological indices. DoseResponse, vol. 18, no. 1, pp. 1559325819899256. http://dx.doi. org/10.1177/1559325819899256. PMid:32165871.

BARTELS, H. and BOBMER, M., 1972. Kinetic determination of creatinine concentration. Clinica Chimica Acta, vol. 37, pp. 193-197.

BEUTLER, E., DURAN, O. and KELLY, B.M., 1963. Improved method for the determination of blood glutathione. The Journal of Laboratory and Clinical Medicine, vol. 61, pp. 882-888. PMid:13967893.

BLAIR, H.A. and PLOSKER, G.L., 2015. Diclofenac sodium injection (Akis $®$, Dicloin $®$ ): a review of its use in the management of pain. Clinical Drug Investigation, vol. 35, pp. 397-404.

CHEN, T., JIN, X., CRAWFORD, B.H., CHENG, H., SAAFIR, T.B., WAGNER, M.B., YUAN, Z. and DING, G., 2012. Cardioprotection from Oxidative Stress in the Newborn Heart by Activation of PPAR $\gamma$ Is Mediated by Catalase. Free Radical Biology \&
Medicine, vol. 53, no. 2, pp. 208-215. http://dx.doi.org/10.1016/j. freeradbiomed.2012.05.014. PMid:22609424.

CHOUDHURY, D. and AHMED, Z., 2006. Drug associated renal dysfunction and injury. Nature Clinical Practice Nephrology, vol. 2, no. 2, pp. 80-91. http://dx.doi.org/10.1038/ncpneph0076. PMid:16932399.

CROFFORD, L.J., 2013. Use of NSAIDs in treating patients with arthritis. Arthritis Research E Therapy, vol. 15, no. 3, suppl. 3, pp. S2. http://dx.doi.org/10.1186/ar4174. PMid:24267197.

DACIE, J.V. and LEWIS, S.M., 1991. Practical hematology. 7th ed. London: Churchill, pp 37-58.

DEMIRBAS, A., 2005. $\beta$-Glucan and mineral nutrient contents of cereals grown in Turkey. Food Chemistry, vol. 90, no. 4, pp. 773-777. http://dx.doi.org/10.1016/j.foodchem.2004.06.003.

DHANVIJAY, P., MISRA, A.K. and VARMA, S.K., 2013. Diclofenacinduced acute renal failure in a decompensated elderly patient. Journal of Pharmacology \& Pharmacotherapeutics, vol. 4, no. 2, pp. 155-157. http://dx.doi.org/10.4103/0976-500X.110916. PMid:23761717.

DILIS, V. and TRICHOPOULOU, A., 2009. Nutritional and health properties of pulses. Mediterranean Journal of Nutrition and Metabolism, vol. 1, no. 3, pp. 149-157. http://dx.doi.org/10.3233/ s12349-008-0023-2.

EBAID, H., BASHANDY, S.A.E., ABDEL-MAGEED, A.M., AL-TAMIMI, J., HASSAN, I. and ALHAZZA, I.M., 2020. Folic acid and melatonin mitigate diabetic nephropathy in rats via inhibition of oxidative stress. Nutrition \& Metabolism, vol. 17, no. 1, pp. 6. http://dx.doi. org/10.1186/s12986-019-0419-7. PMid:31956332.

EL-MADDAWY, Z.K.H. and EL-ASHMAWY, I.M., 2013. Hepato-renal and hematological effects of diclofenac sodium in rats. Global Journal of Pharmacology, vol. 7, no. 2, pp. 123-132.

ENENDU, A.C., UNEKWE, P.C., ESIMONE, C.O., OBI, E. and CHILAKA, K.C., 2016. Protective effect of phenylalanine and glycine onchloramphenicol-induced bone marrow toxicity in albino rats infected with Klebsiella Pneumoniae. International Journal of Biological and Chemical Sciences, vol. 10, no. 1, pp. 369-383. http://dx.doi.org/10.4314/ijbcs.v10i1.28.

ESSEX, M.N., ZHANG, R.Y., BERGER, M.F., UPADHYAY, S. and PARK, P.W., 2013. Safety of celecoxib compared with placebo and nonselective NSAIDs: cumulative meta-analysis of 89 randomized controlled trials. Expert Opinion on Drug Safety, vol. 12, no. 4, pp. 465-477. http://dx.doi.org/10.1517/14740338.2013.78059 5. PMid:23506230.

FARIS, M.A.E., TAKRURI, H.R. and ISSA, A.Y., 2013. Role of lentils (Lens culinaris $L$.) in human health and nutrition: a review. Mediterranean Journal of Nutrition and Metabolism, vol. 6, no. 1, pp. 3-16. http://dx.doi.org/10.1007/s12349-012-0109-8.

FAULKER, W.R. and MEITES, S., 1982. Selected methods for the small clinical chemistry laboratory. Washington, DC: American Ass. for Clinical Chemistry, $125 \mathrm{p}$.

FOOD AND AGRICULTURAL ORGANIZATION OF UNITED NATIONS - FAOSTAT, 2011 [viewed 12 January 2021]. Economic and Social Department: The Statistical Division [online]. Available from: http://faostat.fao.org/site/567/DesktopDefault. aspx?PageID=567\#ancor.

FOOD AND AGRICULTURE ORGANIZATION - FAO, 1998. Traditional food plants. Food and Nutrition Paper, pp. 150-154.

GANESAN, K. and XU, B., 2017. Polyphenol-rich lentils and their health promoting effects. International Journal of Molecular Sciences, vol. 18, no. 11, pp. 2390. http://dx.doi.org/10.3390/ ijms18112390. PMid:29125587.

GLANTZ, A.S., 1992. Primer of biostatistics. New York: Mc Graw-Hill. 
GOWDA, S., DESAI, P.B., KULKARNI, S.S., HULL, V.V., MATH, A.A.K. and VERNEKAR, S.N., 2010. Markers of renal function. North American Journal of Medical Sciences, vol. 2, no. 4, pp. 170-173. PMid:22624135.

HICKEY, E.J., RAJE, R.R., REID, V.E., GROSS, S.M. and RAY, S.D., 2001. Diclofenac induced in vivo nephrotoxicity may involve oxidative stress-mediated massive genomic DNA fragmentation and apoptotic cell. Free Radical Biology \& Medicine, vol. 31, no. 2, pp. 139-152. http://dx.doi.org/10.1016/S0891-5849(01)005603. PMid: 11440826 .

HOUSHMAND, G., TARAHOMI, S., ARZI, A., GOUDARZI, M., BAHADORAM, M. and RASHIDI-NOOSHABADI, M., 2016. Red lentil extract: neuroprotective effects on perphenazine induced catatonia in rats. Journal of Clinical and Diagnostic Research: JCDR, vol. 10, no. 6, pp. FF05-FF08. http://dx.doi.org/10.7860/ JCDR/2016/17813.7977. PMid:27504309.

HOY, S.M., 2016. Diclofenac sodium bolus injection ( Dyloject (TM) ): a review in acute pain management. Drugs, vol. 76, no. 12, pp. 1213-1220. http://dx.doi.org/10.1007/s40265-016-0619-7. PMid:27447189.

IHEDIOHA, J.I., OKAFOR, C. and IHEDIOLA, T.E., 2004. The haematological profile of the Sprague Dawley out-bred albino rat in Nsukka, Nigeria. Animal Research International, vol. 1 , pp. 125-132.

JURÁNEK, I. and BEZEK, Š., 2005. Controversy of free radical hypothesis: reactive oxygen species-cause or consequence of tissue injury. General Physiology and Biophysics, vol. 24, no. 3, pp. 263-278. PMid:16308423.

KIM, S. and JOO, K.W., 2007. Electrolyte and acid-base disturbances associated with nonsteroidal anti-inflammatory drugs. Electrolyte \& Blood Pressure, vol. 5, no. 2, pp. 116-125. http:// dx.doi.org/10.5049/EBP.2007.5.2.116. PMid:24459510.

KONYALIOGLU, S., ER, A., UNEY, K., ESLAM, M. and YAZAR, E., 2007. Effect of flunixin meglumin on the antioxidant status in endotoxemia. Acta Veterinaria, vol. 57, no. 2-3, pp. 241-246. http://dx.doi.org/10.2298/AVB0703241K.

KRISHNAN, A.V. and KIERNAN, M.C., 2009. Neurological complications of chronic kidney disease. Nature Reviews Neurology, vol. 5, no. 10, pp. 542-551. http://dx.doi.org/10.1038/ nrneurol.2009.138. PMid:19724248.

LAI, L.H., CHOU, S.Y., WU, F.Y., CHEN, J.J. and KUO, H.W., 2008. Renal dysfunction and hyperuricemia with low blood lead levels and ethnicity in community-based study. The Science of the Total Environment, vol. 401, no. 1-3, pp. 39-43. http:// dx.doi.org/10.1016/j.scitotenv.2008.04.004. PMid:18514766.

LANEUVILLE, O., BREUER, D.K., DEWITT, D.L., HLA, T., FUNK, C.D. and SMITH, W.L., 1994. Differential inhibition of human prostaglandin endoperoxide $\mathrm{H}$ synthases-1 and-2 by nonsteroidal anti-inflammatory drugs. The Journal of Pharmacology and Experimental Therapeutics, vol. 271, no. 2, pp. 927-934. PMid:7965814.

LEE, S., KANG, M. and MIN, H., 2011. Folic acid supplementation reduces oxidative stress and hepatic toxicity in rats treated chronically with ethanol. Nutrition Research and Practice, vol. 5 , no. 6, pp. 520-526. http://dx.doi.org/10.4162/nrp.2011.5.6.520. PMid:22259676.

LUCOCK, M., 2000. Folic acid: nutritional biochemistry, molecular biology, and role in disease processes. Molecular Genetics and Metabolism, vol. 71, no. 1-2, pp. 121-138. http://dx.doi. org/10.1006/mgme.2000.3027. PMid:11001804.

MACDONALD, J., GALLEY, H. and WEBSTER, N., 2003. Oxidative stress and gene expression in sepsis. British Journal of Anaesthesia, vol.
90, no. 2, pp. 221-232. http://dx.doi.org/10.1093/bja/aeg034. PMid: 12538380.

MAHMOUD, A.M., MORSY, B.M., ABDEL-HADY, D.S. and SAMY, R.M., 2015. Prunus armeniaca leaves extract protects against isoniazid and rifampicin induced nephrotoxicity through modulation of oxidative stress and inflammation. International Journal of Food and Nutrition Science, vol. 2, no. 2, pp. 100-105. http://dx.doi.org/10.15436/2377-0619.15.033.

MARTIN, S.J. and SABINA, E.P., 2016. Amelioration of anti-tuberculosis drug induced oxidative stress in kidneys by Spirulina fusiformis in a rat model. Renal Failure, vol. 38, no. 7, pp. 1115-1121. http:// dx.doi.org/10.1080/0886022X.2016.1184940. PMid:27183989.

MIBIELLI, M.A., GELLER, M., COHEN, J.C., GOLDBERG, S.G., COHEN, M.T., NUNES, C.P., OLIVEIRA, L.B. and FONSECA, A.S., 2009. Diclofenac plus $B$ vitamins versus diclofenac monotherapy in lumbago: the DOLOR study. Current Medical Research and Opinion, vol. 25, no. 11, pp. 2589-2599. http://dx.doi. org/10.3111/13696990903246911. PMid:19731994.

MOENS, A.L., CHAMPION, H.C., CLAEYS, M.J., TAVAZZI, B., KAMINSKI, P.M., WOLIN, M.S., BORGONJON, D.J., VAN NASSAUW, L., HAILE, A., ZVIMAN, M., BEDJA, D., WUYTS, F.L., ELSAESSER, R.S., COS, P., GABRIELSON, K.L., LAZZARINO, G., PAOLOCCI, N., TIMMERMANS, J.-P., VRINTS, C.J. and KASS, D.A., 2008. High-dose folic acid pretreatment blunts cardiac dysfunction during ischemia coupled to maintenance of high-energy phosphates and reduces postreperfusion injury. Circulation, vol. 117, no. 14, pp. 18101819. http://dx.doi.org/10.1161/CIRCULATIONAHA.107.725481. PMid: 18362233.

MONTGOMERY, H.A.C. and DYMOCK, J.F., 1961. The determination of nitrite in water. Analyst, vol. 86, pp. 414-416.

MUTAVDZIN, S., GOPCEVIC, K., STANKOVIC, S., UZELAC, J.J., BOROVIC, M.L. and DJURIC, D., 2019. The effects of folic acid administration on cardiac oxidative stress and cardiovascular biomarkers in diabetic rats. Oxidative Medicine and Cellular Longevity, vol. 2019, pp. 1342549.

OGBERA, A.O., DADA, O., ADEYEYE, F. and JEWO, P.I., 2010. Complementary and alternative medicine use in diabetes mellitus. West African Journal of Medicine, vol. 29, no. 3, pp. 158-162. http://dx.doi.org/10.4314/wajm.v29i3.68213. PMid:20665458.

ORINYA, O.A., ADENKOLA, A.Y. and OGBE, R.J., 2016. Haematological and biochemical studies on the effect of diclofenac sodium on Wistar Rattus norvegicus. International Journal of Biological and Chemical Sciences, vol. 10, no. 5, pp. 2231-2242. http://dx.doi. org/10.4314/ijbcs.v10i5.23.

PAGET, G.E. and BARNES, J.M., 1964. Toxicity tests. In: D.R. LAURENCE and A.L. BACHARACH, eds. Evaluation of drug activities: pharmacometrics. London: Academic Press, vol. I, pp 135-166. http://dx.doi.org/10.1016/B978-1-4832-2845-7.50012-8.

PONCE-MONTER, H.A., ORTIZ, M.I. and GARZA-HERN'ANDEZ, A.F., 2012. Effect of diclofenac with $B$ vitamins on the treatment of acute pain originated by lower-limb fracture and surgery. Pain Research and Treatment, vol. 2012, pp. 104782.

RODAK, L.C., 1995. Routine testing in hematology. In: B.F. Rodak, ed. Diagnostic hematology. Toronto: W.B. London, pp 128-144.

SAKR, S., HASSANIEN, H., BESTER, M., ARBI, S., SOBHY, A., NEGRIS, H. and STEENKAMP, V., 2018. Beneficial effect of folic acid on kidney and testes of adult albino rats after exposure to methomyl. Toxicology Research, vol. 7, no. 3, pp. 480-491. http://dx.doi. org/10.1039/C7TX00309A. PMid:30090598.

SALOMON, L., LEVU, S., DERAY, G., LAUNAY-VACHER, V., BRUCKER, G. and RAVAUD, P., 2003. Assessing residents' prescribing behavior in renal impairment. International Journal for Quality in Health 
Care, vol. 15, no. 3, pp. 235-240. http://dx.doi.org/10.1093/ intqhc/mzg034. PMid:12803351.

SAMSON, E.S., OLASUNKANMI, A.K. and JOEL, J.S., 2012. Haematological and hepatotoxic potential of onion (Allium cepa) and garlic (Allium sativum) extracts in rats. European Journal of Medicinal Plants, vol. 2, no. 4, pp. 290-307. http:// dx.doi.org/10.9734/EJMP/2012/1517.

SINGH, J., 2018. Folate content in legumes. Biomedical Journal of Scientific \& Technical Research, vol. 3, no. 4, pp. 3475-3480. http://dx.doi.org/10.26717/BJSTR.2018.03.000940.

SOLINI, A., SANTINI, E. and FERRANNINI, E., 2006. Effect of shortterm folic acid supplementation on insulin sensitivity and inflammatory markers in overweight subjects. International Journal of Obesity, vol. 30, no. 8, pp. 1197-1202. http://dx.doi. org/10.1038/sj.ijo.0803265. PMid:16491109.

SOLTAN, S.S.A., 2013. The protective effect of soybean, sesame, lentils, pumpkin seeds and molasses on iron deficiency anemia in rats. World Applied Sciences Journal, vol. 23, no. 6, pp. 795-807.

SZÍVÓS, K. and PUNGOR, E., 1974. Determination of calcium, sodium, potassium and magnesium in human blood sera by atomic absorption. Acta Pharmaceutica Hungarica, vol. 44, no. 6, pp. 253-261. PMid:4215286.

TECLU, D., TIVCHEV, G., LAING, M. and WALLIS, M., 2009. Determination of elemental composition of molasses and its suitability as carbon source for growth of sulphate - reducing bacteria. Journal of Hazardous Materials, vol. 161, no. 2-3, pp. 1157-1165. http://dx.doi.org/10.1016/j.jhazmat.2008.04.120. PMid: 18541372.
THAVARAJAH, D., JOHNSON, C., MCGEE, R. and THAVARAJAH, P., 2015. Phenotyping nutritional and antinutritional traits. In: Kumar J, Pratap A, eds. Phenomics in crop plants: trends, options and limitations. New Delhi: Springer, pp. 223-233.

TIETZ, N.W., 1987. Fundamentals of clinical chemistry. 3rd ed. Philadelphia: W.B. Saunders Co, pp. 874.

UNITED STATES DEPARTMENT OF AGRICULTURE - USDA, 2010 [viewed 10 January 2021]. Database for the Oxygen Radical Absorbance Capacity (ORAC) of selected foods. Beltsville: USDA. Available from: http://www.ars.usda.gov/SP2UserFiles/ Place/12354500/Data/ORAC/ORAC_R2.pdf.

UNITED STATES DEPARTMENT OF AGRICULTURE - USDA, 2011. USDA National Nutrient Database for Standard Reference. Beltsville: USDA. Available from: http://www.ars.usda.gov/ research/publications/publications.htm?seq_no_115=243584.

VASUDEVAN, D.M. and SREEKUMARI, S., 2007. Textbook of biochemistry for medical students. 5th ed. New Delhi: Jaypee Brothers Medical Publishers Ltd.

VERHAAR, M.C., STROES, E. and RABELINK, T.J., 2002. Folates and cardiovascular disease. Arteriosclerosis Thrombosis and Vascular Biology, vol. 22, no. 1, pp. 6-13.

YAPAR, K., ATAKISI, O., UZLU, E., CITIL, M., UZUN, M. and ERDOGAN, H.M., 2008. Protective effect of L carnitine against diclofenac sodium toxicity in mice. Revue de Medecine Veterinaire, vol. 159, no. 6, pp. 363-367.

YOUNG, D.S., 2001. Effects of disease on clinical lab.tests. 4th ed. Washington, DC: AACC Press. 